\title{
Toward Integration: Disciplines, Specialties and Journals
}

\author{
Thomas Scheff
}

Published online: 7 January 2015

(C) Springer Science+Business Media New York 2015

Specialization is the way to start a discipline, but it must not become a religion. When rigid, it is an impediment to advancing knowledge: the more rigidly specialized, the less relevant to advancing knowledge. Currently this rigidity seems to be the key problem in social and behavioral studies and in the humanities as well. For example, it seems clear that complete adherence to what psychologists think of as the scientific method has brought the discipline to a virtual standstill. Two examples: "aggression catharsis" and self-esteem.

For many years psychologists have been conducting experiments that show that venting anger doesn't work. This is an extremely important finding because the majority of the public thinks that venting is a good idea: it gets the anger "off your chest." However, the researchers made the appalling error of confounding venting with catharsis. Being scientistic allows them to ignore the large literature in the humanities that has developed a complex model of catharsis. According to this model, venting is not a form of catharsis. Arousing anger in a theatre audience is meant to let them feel suppressed emotions safely, not cause a riot.

The second example is the study of self-esteem. Over the last 50 years there have been more than 20,000 studies using self-esteem scales and other reliable methods, such as systematic social surveys. Yet these scales refuse to predict behavior: the variance has always been under $5 \%$, practically zero. One of the problems with the some 200 different scales that have been used may concern their validity, rather than their reliability: the scales all confound thoughts (such as egotism) with emotions (such as authentic pride.)

The case of modern psychology is reminiscent of Tycho Brahe's attempt in the 16th century to determine the orbit of Venus. A skilled and systematic astronomer, he made hundreds of accurate chartings of the orbit. But he couldn't determine it because he assumed, like everyone else, that the planets revolved around the earth.

After Brahe's death, his assistant, Johannes Kepler, took on the task. But even with Brahe's data, he couldn't solve the problem either. In his exasperation, Kepler tried a new approach: he built what might be thought of as a case study: using translucent materials he constructed a model of the planetary orbits. To his surprise, it predicted the

T. Scheff $(\bowtie)$

University of California, Santa Barbara, CA 93106, USA

e-mail: scheftj@cox.net 
correct orbit for Venus. What had happened was that Kepler had accidentally placed the sun rather the earth in the center. He had inadvertently used what Blaise Pascal called "finesse," intuition rather than system, to solve the problem.

An early scientist, Pascal (1660) foresaw our current problem. He thought that advances in understanding require both "the spirit of geometrie" (system) and "the spirit of finesse" (intuition). Intuition creates new ideas by jumping over existing assumptions, system is needed to test their validity and refine them if they are valid. If this is true, the social sciences and the humanities badly need each other.

\section{Sociology as a Discipline}

More recently, the eminent biologist E. O. Wilson (1998) has also written on this issue, pleading for what he calls "consilience," the integration of various forms of knowledge. Wilson has several pages of criticism of each of the major social science and humanities disciplines, including economics, psychology, and history. One of his comments on sociology concerns a quote from a leading sociologist of that time (Coleman 1990):

"The principal task of the social sciences is the explanation of social phenomena, not the behavior of single individuals."

Wilson takes issue with this idea, still strongly held by most sociologists, by noting that biology would have remained stuck in its 1850 position if it had stayed at the level of the whole organism, refusing to include cells and molecules. Perhaps in the beginning, pure sociology was a virtue, but treating it as the only way has become a vice.

Durkheim's (1901) study of suicide gave birth to modern sociology, showing a social component in causation, independent of individuals. This is an important first step, but it is not much help for understanding suicide, because the relationship is tiny. The more obvious meaning of Durkheim's findings and its replications is that the social component is NOT the major cause, or even one of the most important causes.

Alfred North Whitehead, a philosopher of science, made an important point about advancing learning:

A clash of doctrines is not a disaster - it is an opportunity... In formal logic, a contradiction is the signal of a defeat; but in the evolution of real knowledge it marks the first step in progress toward a victory. (1962, pp. 266-267).

Koestler (1967) had proposed a similar idea that he called "bi-sociation," being able to entertain two utterly different points of view simultaneously, by moving quickly back and forth between them (Turner and Fauconnier 2002). He thought all real advances were born in this way.

It would be difficult to exaggerate the importance of these ideas: BISOCIATE OR ROT. Every discipline lives in what has been called an "assumptive world," beliefs and practices so hallowed that they go without saying, taken completely for granted. Disciplines, for the most part, live in two assumptive worlds. The first is the particular outlook of the discipline itself. For example, most sociologists assume without thinking 
about it, that limiting study to the social/cultural world, and excluding the individual is the only way to go. Just as strongly, academic psychologists are completely and irrevocably sold on using the scientific method and NO OTHER. These assumptions are no longer viable, but that doesn't seem to matter.

A second world that researchers live in is the assumptive world of the larger society of which they are all a part. One example: until recently, none of the social/behavioral sciences or humanist departments had sections on emotions. Emotions are at least as important as behavior, cognition, perception, economics, politics, ecology, and so on, but they are still getting short shrift, at best. Relying on unconsidered assumptions tends to block advances of knowledge completely. Interdisciplinarity sounds a generic wakeup call: the earth is not flat.

One step would be to encourage some researchers to become generalists after their initial training in a discipline or sub-discipline. This step would not compete with disciplines, but increase the number of those who attempt to integrate. At present, the number of generalists seems tiny. A second step would be to establish an institute for generalists. The last step would be departments specifically oriented to interdisciplinarity.

\section{Part/Whole: An Interdisciplinary Path}

One of the first philosophers of science, Spinoza (1632-1677), outlined what amounts to a method for achieving bisociation about humans. He proposed that human beings are so complex that to even begin to understand them, one needs to move rapidly back and forth between "the least parts and greatest wholes." What he called least parts were concrete particulars; "greatest wholes", abstract ideas, concepts and theories. (Sacksteder 1991; Scheff 1997). William Blake stated a similar idea in one sentence: "Art and science cannot exist but in minutely organized particulars." (c. 1820).

Everyone uses Spinoza's method unthinkingly in daily life. Everyday discourse would be impossible to understand in any other way, since if taken literally, it is fragmented, ambiguous, and incomplete. In this case the least parts are the words, gestures and paralanguage, and the greatest wholes the meanings constructed from these least parts.

A comparison of the work of two master sociologists, Cooley (1922) and Goffman (1959), can illustrate the relationship between parts and wholes, especially the need for balance between them (Scheff 2014). Cooley provided brilliant wholes in the form of general propositions, but insufficient parts, Goffman, brilliant parts, in the form of concrete examples and new concepts, but not enough wholes, in the form of explicit hypotheses.

\section{Examples of Integrative Studies}

The sociologist Norbert Elias's expansive study of modernization (1939 in German; 1994) involved a textual analysis of etiquette and educational manuals over a 500-year period of European history in three languages. By close examination of the texts, he found evidence that as shame took the place of physical punishment, it also became 
increasingly invisible. Although this study is widely recognized as his masterpiece, it still has not gotten the credit it deserves. One reason, perhaps, is that as he demonstrated the invisibility of shame in modern societies, his own study is less visible than it should be for this reason (Using Google Ngrams 1800-2000 in five languages, my recent study [Scheff 2014] finds empirical support for Elias's shame thesis).

A study of Freud's writings, both his cases and his own letters, by the psychologist Michael Billig (1999) used a close textual analysis to reconstruct the psychoanalytic theory of repression. His study showed that repression seems to be caused by social practices: parents teach children to avoid certain issues (such as sexuality and anger) by distracting them to the point that the children learn to also distract themselves. It would seem that psychoanalytic theory, which is entirely psychological, needs a strong social component.

An earlier article (Scheff 2000) provides specific examples of the way that the novels of Virginia Woolf foretold key ideas in the social sciences. The most surprising is her treatment of what is now called "role-taking" in thought, how we live in the minds of others without realizing it. The social philosopher G. H. Mead (1934) and his many followers developed a whole social psychology around it, now called Symbolic Interaction.

Seven years before Mead's book (1934), Woolf's 1927 novel To the Lighthouse was largely based on Woolf's taking the role of her own mother, who is the basis for Mrs. Ramsay, the leading character. Woolf's intuitive understanding of the process of roletaking is made unmistakably clear in a part of Mrs. Ramsay's interior monologue that critics have come to call "The Brown Stocking" episode (Auerbach 1953). Auerbach gave it this name because it takes place during a few seconds when Mrs. Ramsay is trying on the stocking she is knitting on her son's ankle. It is of interest that Auerbach, who first reported the psychological depth of this incident, threw up his hands over the Ramsay-Bankes inner dialogue that is described below.

The last part of the two pages of interior monologue begins with what seems to be an actual dialogue, a phone conversation between Mrs. Ramsay and William Bankes. But the phone conversation is taking place not from Mrs. Ramsay's point of view, but from Banks's. The section starts with a compliment that Banks pays to Mrs. Ramsay, that "Nature has but little clay like that of which she moulded you." After further compliments, Bankes states, either to Mrs. Ramsay or to himself, that yes, he would catch the 10:30 train, which is what the phone call is ostensibly about.

The point of view is obviously not Mrs. Ramsay's, but Banks's. How could this be? What Woolf seems to be doing is showing that Mrs. Ramsay imagined a sequence of events beginning with an actual compliment to herself, but then going on to carry through the compliment to a sequence of thoughts and activities as they might have occurred to Bankes.

Mrs. Ramsay knew that Bankes was an admirer of hers, and she also knew his habits quite well. She is thinking of the problem of Mrs. Ramsay and her beauty from the point of view of an admirer of hers. She is imagining herself from Mr. Bankes' point of view, as Woolf, in the two monologues, is imagining the world from Mrs. Ramsay's point of view, a world within a world. Just as Mrs. Ramsay was able to plausibly construct the world from Mr. Banks's point of view, because she knew him well, so Virginia Woolf was able to plausibly construct the world from Mrs. Ramsay's point of view, since she knew so well the model (her own mother, Julia Stephen). 
When Woolf's sister Vanessa read To the Lighthouse, she wrote to Virginia “...you have given a portrait of mother which more like her than anything I could ever have conceived possible. It is almost painful to have her so raised from the dead. ... as far as portrait painting goes you seem to me to be a supreme artist..." (Lee 1997, pp. 473474). But she was not only an artist, but could have also been an inspiration to social scientists.

Woolf has her protagonist, Mrs. Ramsey, "living in the mind of others (as with Mr. Bankes) without knowing it," as Cooley would have it. But the Ramsey-Bankes episode shows that Woolf knew that she was living in the mind of her mother, because she has her mother do the same thing with Bankes that she was doing with her mother. Such a specific, concrete and detailed example of role-taking is totally absent in Cooley's writing, and although present, not made explicit in Goffman's.

Another thing that is illustrated concretely in Woolf's writing that is absent from Cooley and only implicit in Goffman is the reason that people don't know it: the incredible speed of inner speech. All of the interior monologues in Woolf's work, but especially The Brown Stocking episode, clearly show that it is hundreds, if not thousands, of times faster than external speech. Current studies of consciousness have yet to catch up with Woolf in this matter. The division between the humanities and the rest of the disciplines seems particularly difficult to change.

Linkoping University in Sweden began organizing departments in terms of "themes" rather than disciplines in 1980, which suggests a strong emphasis on interdisciplinarity, both in research and teaching. However, the current arrangement (http://www.liu.se/ en/?l=en) suggests that some traditional divisions are still in place:

- Faculty of Arts and Sciences

- Faculty of Health Sciences

- Faculty of Educational Sciences

- Institute of Technology

Perhaps the next major step is to organize departments or institutes that incorporate the humanities in with the social and physical sciences.

\section{Conclusion}

As already indicated, Pascal (1660) long ago implied that the sciences and humanities need each other, and all disciplines and sub-disciplines as well. Specialization is still a good idea, but it must not become an end itself. Rather it should be balanced by integration between specialties. If this is true, the social sciences and the humanities need to connect, and also the disciplines and sub-disciplines within and between them. It therefore seems that there should be groups in all social and humanities disciplines trying interdisciplinary or other new approaches, and that this is a crucially important matter.

The issue is important far beyond the universities. Unlike other species of creatures, humans have become capable of destroying other humans en masse, even ALL other humans. Ironically, this capability is a function of the huge advances of knowledge in the physical sciences. We are very near, or may have arrived at the point where a single "shooter" is capable of destroying us. 
In these dangerous times, perhaps one interdisciplinary theme would be to find out what leads to the kind of autism-like syndrome that severs all empathy for other humans. Empathic connectedness with other members of the species is hardwired into humans just as it is in other mammals (Icaboni 2008, pp. 264-265). What are the social, psychological, economic and political mechanisms that lead to disconnection and complete alienation from others both at the interpersonal and intergroup levels? If all disciplines would start working together on this problem, we may be able to solve it before it's too late.

\section{References}

Auerbach, E. (1953). Mimesis: The representation of reality in western literature. Princeton: Princeton University Press.

Blake, W. (1820). Jerusalem, Ch. 3, plate 55, lines 60-75.

Billig, M. (1999). Freudian repression. Cambridge: Cambridge U. Press.

Coleman, J. (1990). Foundations of social theory. Cambridge: Harvard University Press.

Cooley, C. (1922). Human nature and the social order. New York: Charles Scribner's Sons.

Durkheim, E. (1901). Suicide. Glencoe: Free Press (1951).

Goffman, E. (1959). The presentation of self in everyday life. Garden City: Doubleday/Anchor Books.

Icaboni, M. (2008). Mirroring people. New York: Farrar, Straus and Giroux.

Koestler, A. (1967). The act of creation. New York: Dell.

Lee, H. (1997). Virginia Woolf. New York: Knopf.

Mead, G. H. (1934). Mind, self, and society. Chicago: U. of Chicago Press.

Pascal, B. (1660). Pensees. (Thoughts). Paris: Editions du Cerf. (1982).

Sacksteder, W. (1991). Least parts and greatest wholes: variations on a theme in Spinoza. International Studies in Philosophy, 23(1), 75-87.

Scheff, T. (1997). Emotions, the social bond, and human reality: Part/whole analysis. Cambridge: Cambridge University Press.

Scheff, T. (2000). Multipersonal dialogue in consciousness. Journal for the Study of Consciousness, 7, 3-19.

Scheff, T. (2014). Toward defining basic emotions. Qualitative Inquiry, 24, 1-11.

Turner, M., \& Fauconnier, G. (2002). The way we think. Conceptual blending and the mind's hidden complexities. New York: Basic Books.

Whitehead, A. (1962). Science and the modern world. New York: Macmillan.

Wilson, E. O. (1998). Consilience. New York: Knopf.

Woolf, V. (1927). To the lighthouse. New York: Harcourt (1989). 